\title{
The political vow of Jephthah in Judges 11:30-31
}

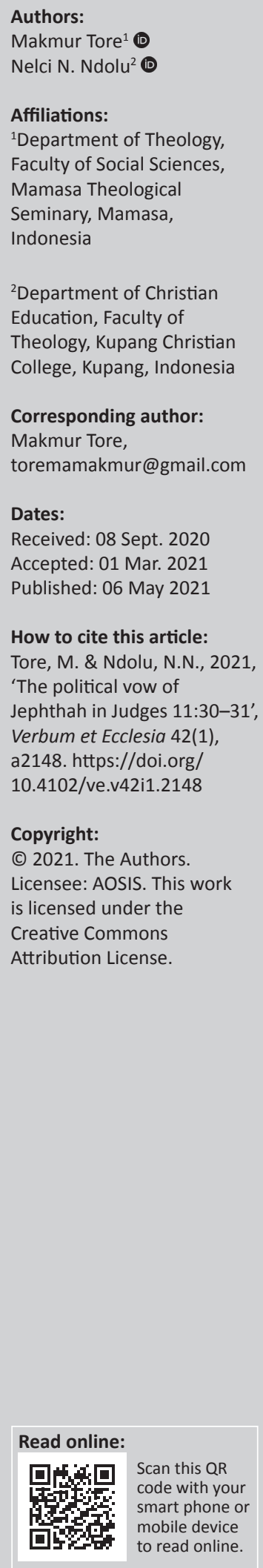

This study responds to Jephthah's ambiguous vow that led to a heart-wrenching and outrageous tragedy. There are conflicting ideologies held by Jephthah and the Deutronomist tradition in laying the biblical theology foundations. The church is challenged to be vigilant in vowing. To achieve this goal, the text of Judges 11:30-31 is explored by using an ideological critique approach. The focus of this study is to underline the concept of Jephthah's ideology of victory on the fighting against the enemy of Israel as a political way to prove one's identity and get out of social discrimination at the expense of everything including his own family. Jephthah's act was not aligned with what the Deuteronomists promoted. Attempts to incorporate any sacrificial foreign cult (including anyone) resulted in deep scars on the faith history of the Israelites. In addition, it shows that Jephthah's leadership, which is contrary to God's ideals, is unable to maintain its existence in international relations when it is able to maintain its religious exclusivity. This study contributes to the interpretation of biblical texts by exposing the ideological aspects of the reader to take the right stance to be aware of the tendency to cause gender violence with a vow.

Intradisciplinary and/or interdisciplinary implications: This is a multidisciplinary study because it integrates biblical hermeneutics with the context of the political constellation of Christian leaders. Apart from that, it serves as a reference for reflection and dialogue that corrects, criticises or legitimises the situation in the context of ideology, history, poverty, social conflicts, political problems and gender justice for readers.

Keywords: political vow; Judges 11:30-31; Jephthah; ideology of victory; deuteronomistic tradition.

\section{Introduction}

The story of Jephthah who sacrificed his daughter to fulfil his vow to God, as well as the allied fighting between him and the Ephraimites in Judges 11:29-40, is a tragic story that is both confusing and heartrending. Jephthah had vowed to the Lord that if he returned safely from fighting the Ammonites, he would offer something that came out of his house as a burnt offering to the Lord. It is not clear what kind of votive sacrifice Jephthah was thinking. Unfortunately, it was his daughter who left the house to greet Jephthah. The girl was Jephthah's only child. Jephthah was very disappointed but felt obliged to fulfil his vow to the Lord. Jephthah's daughter begged her father to give her 2 months to cry over her virginity in the mountains with her friends. Jephthah accepted his daughter's request. After 2 months, the girl returned to her father. Jephthah did to her according to what he had vowed.

Previous commentators have analysed the ethical aspects of the text. Pseudo-Philo (1985:10-11) makes a strong condemnation of Jephthah. He judged Jephthah's vow to have angered Yahweh. Jephthah said:

[W] hoever is the first to come through the doors of my house to meet me when I return safely from fighting the Ammonites - he will belong to the Lord and I will offer him up as a burnt sacrifice. (Jdg 11:31)

Yahweh would ask what if Jephthah met his dog for the first time, will he also offer it to Yahweh? Meanwhile, Ambrosius defended Yefta instead. Ambrose (1975:264) states that Jephthah's vow were not deliberate vow, they were simply unthinkable. He appreciates Jephthah because in the end he regretted his vow but still manifested it with fearful piety and reverence for God, and himself marked by the tearing of his clothes became a reference to the annual tradition of weeping for his daughter.

Thomas Aquinas (1225-1274 AD), a Dominican theologian, interpreted the sacrifice of Jephthah's daughter as a picture of the blood sacrifice of Christ. He criticised Jephthah's vow, but at the same 
time their arguments implicitly show aspects of Jephthah's defence. Augustine (1995:149) saw Jephthah and Gideon, who both received the Spirit of God and both erred in God's trials, as a lesson that God also used the flawed in His work. It is important that ideological motives are analysed so that the tragic and confusing impression on the text can be understood according to the author's context, the text's context and according to the context of the reader and interpreter (Yee 1999:150). The purpose of this article is to explain the socio-political ideology in the Yeptah oath. The strategy used to achieve this goal is to identify the previous interpreters' ideological interpretations. Furthermore, specific ideological elements in the socio-political context of the text are elaborated for the readers of the text.

\section{The challenge of ideological criticism}

Ideological criticism is an approach that seeks to examine the assumptions and beliefs of the writers and readers of the Hebrew Bible in identifying and evaluating royal systems, cult ideologies, democratic political system practices, education and media, as well as customary behaviour in the family and formal gatherings and informal social events in ancient Israel (Clines 1995:9-11). The method of ideological criticism consists of extrinsic and intrinsic analyses (Yee 1999:50). Extrinsic analysis seeks to understand the social structures of certain historical groups and their interrelation with other parts of society, and for this endeavour social sciences and historical criticism are needed in the process of analysis. In other words, if extrinsic analysis pays attention to the ideological context that shapes the text, then intrinsic analysis pays attention to the text as a reproduction of ideology. Referring to Macherey (1978:85) who said that 'to say something there are other things that must not be said', Yee believes that intrinsic analysis must focus attention on things that do not exist in the text. This assumption states that a statement can be accepted as truth if other contrary truths are not stated.

In this case, intrinsic analysis takes a perspective from a position opposite to the text by asking what voices are excluded: perhaps women, other ethnic groups or the poor. Intrinsic analysis uncovers voices that are considered competitors and marginalised by power structures in society. In addition, according to Yee (1995:152), intrinsic analysis seeks a deep investigation of the rhetoric of the text; that the artistic nature of the text influences the reader to accept the particular ideology it wishes to convey. Therefore, this analysis pays attention to the rhetorical elements of the text, such as symbols, irony and other language expressions. The narrative elements of the text will also be considered insofar as they are considered to be 'doors' to reveal existing ideologies. From this definition Yee concludes that ideology encourages and convinces individuals to internalise unreal relationships with the real world. Ideology serves to generate reality for society, to make clear the often confusing world, even though ideology is not a statement that really explains the whole. Hence, ideology is an idea that can be the basis for social control or social resistance.

\section{Ideological readings of Judges 11:30-31}

The text of Judges develops in three stages: predeuteronomistic sources, deuteronomistic composition and post-deuteronomistic additions (McKenzie 2010:59). The context that influences the formation of the ideology of text production provides a guide for understanding the main ideas that the Deuteronomist editors want to convey through the text of Judges 11:30-31. Deuteronomist editors working on various tributaries (Babylonian era) emphasised at least three main ideas, namely the dangers of syncretic religious identity, the risk of political leadership of elites and clans in the North and the importance of gender control.

Firstly, the criticism of syncretic religious identity: The syncretic cult, in which Yahweh was worshiped with other gods or in various ways, is seen as a form of cult-political affiliation with foreigners and is considered the cause of the formation of many factions, so that the Deuteronomists are seen as an obstacle to the realisation of national glory. Deuteronomist editors, working in a variety of tributaries, opposed the practice of such cults and emphasised the purity of the cult characterised by the centrality of the cult in Jerusalem. To demonstrate the dangers of syncretic worship (foreign syncretism more precisely), the Deuteronomists describe the chaos caused by syncretic cults and offer cult rules as a solution (Smith 1987:103). To examine the negative aspects of Jephthah's vow, Janzen (2005:341) argued that the Deuteronomist's main aim of telling Jephthah's story was to educate his listeners that 'when the Israelites followed foreign worship practices, they would act in a foreign way'. The Deuteronomist establish cult sanctification of 'Yahweh only' tragic story of the daughter of Jephthah as a symbol of the chaos, which follows syncretic cult practices, is enacted. The vow to Yahweh carried elements of a foreign cult. The syncretistic character of Jephthah's vow as referred to by Janzen is evident in his vow.

Jephthah intended humans to be an offering (burnt) for the fulfilment of his vow said, 'hayyotse asyer yetse middaltê bêtîliqrâtî...' (whatever or whoever he is who comes out of my door to meet me...). Jephthah relied on his cleverness in negotiating with the elders of Gilead. Jephthah tried to play luck with Yahweh. Perhaps Jephthah hoped his flocks would come out to meet him when he returned home to war, even though that possibility was slim. It is rather difficult to imagine Jephthah's ox, cow, sheep or goat coming out to meet (liqrâtî) his master who returned from fighting. Some commentators believe that Jephthah meant human sacrifice. There is no complete description of Jephthah's family membership. Judges 11:34 provides information that Jephthah only had a single daughter. But the sound of his vow which says '... whoever or whatever he is (masculine) comes out of my door to meet me ...' gives an indication that Jephthah's family members are not just his wife and daughter. Perhaps Jephthah who had been the leader of the thugs in Tob's land had servants or slaves in his house (Meyers 1997:18-19). 
Logan (2009:668-669) showed evidence that in the tradition of Western Semitic cult in general, human sacrifice became the practice of worship. In the pre-exilic Judaic cult there were groups that viewed child sacrifice as part of a devotional service that greatly satisfied Yahweh. Pressler (2002:203) argued that the gravity of the challenges faced and Jephthah's desire to restore his good name made him ready to give anything, including the sacrifice of human life. Meanwhile, O'Connell (1996:192) argued that Jephthah made human sacrifice to strengthen his social status in Gilead. Jephthah expected one of the family members but not his daughter. However, if we are consistent in the formulation of Jephthah's sentence, then we have to assume that he has hoped for livestock or family members, and then this sentence still carries a risk to human life. Because whoever comes out of the house to meet him will be offered (burnt). So, as long as he won, he would offer all who lived in his house, including humans, as a burnt offering to Yahweh. Jephthah considered the stakes worth his request, namely the lives of the children of Ammonites. Blood is paid for with blood (Cartledge 1992:32). Jephthah's intention to risk human life and livestock as an offering to Yahweh was against Deuteronomic law (Webb 1987:64). Deuteronomy 12:31 contains a prohibition against offering humans as sacrifices to Yahweh. According to the law, human sacrifice was a foreign cultic practice that the Israelites had to avoid. Human sacrifices, especially children, are associated with Moloch (2 Ki 23:10; Jr 32:35). Moloch is the god of the Ammonites and is often associated with a vow. In the logic of the Deuteronomic law, Jephthah's intention to make a vow to offer a human sacrifice to Yahweh was a form of cult syncretism. The narrator presents Jephthah's vow as an irony. Jephthah fought against foreign nations, but instead adopted foreign rites, for his victory.

The chaos that Jephthah's vow caused was not because of the influence of the cult of foreigners alone. Malina's (1996:26-44) categorisation of cults shows the tension between domestic cults and political cults in Jephthah's vow. Aspects of the political cult of Jephthah in Judges are evident in his admission that Yahweh is the judge $(11: 11,27)$ who has the power to give victory $(11: 9,30 \mathrm{~b} ; 12: 3 \mathrm{~d})$. Jephthah would give something that belongs to Yahweh in return (11:31b). Aspect of the domestic cult was characterised by the use of the term burnt in the fulfilment of the vow (11:31c) and Jephthah's own offering of sacrifices (11:39b). As explained by Yee, the author or editor offers a cult according to the tributary variety or in Malina's term 'political cult' and invites to move away from the cult according to the familial variety in Malina's term 'domestic cult'. Thus, the confusion could only be overcome if Jephthah took a full vow with the motives and methods according to the laws of cult politics (various tributaries).

Jephthah made a vow to Yahweh who is the Judge. Jephthah's view about the political God is evident in his understanding of Yahweh's relationship with Israel as the relationship between people and masters (11:23). Jephthah persuaded Yahweh by promising a burnt offering but confirmed it with the phrase wehayya la-Adonai (belonging to Yahweh; 11:31b).
This emphasis echoes the meaning of tribute to rulers rather than respect for ancestors (Malina 1996:26-30). The understanding of a political God influenced Jephthah in formulating his vow. Jephthah understand that relationship between the Judge and defendant risked all the people or the judge and defendant, Jephthah risked all the people of his house as a vow offering for Yahweh. In tribal cult, the understanding of ancestral and hereditary relations, such stakes are irrelevant, because the entire contents of the house of adorers are the property of the ancestral God who was given to them. God the ancestor has the right to take it at any time as it appears in God's request to Abraham to offer up Isaac so that it is more relevant if the worshiper gives a sacrifice to prevent or give thanks rather than risking it (Gn 22:1-2). The comparison shows that Jephthah's vow contradicts a political God understanding and a domestic God understanding. He played the God of politics by playing chance: 'whatever comes out of my door'. On the contrary, Jephthah ignored the aim of the domestic cult as an effort to keep the family and clan alive.

Another factor that messed up Jephthah's vow was his vow to give Yahweh an offering (burnt) if his request was granted. According to Singgih (2018:140), in the priestly law of the Pentateuch, which came into being several centuries after the Jephthah period, the fulfilment of a vow should not be burnt, but zebakh shelayim. According to cult political standards, characterised by cult law, the object of Jephthah's offering was wrong. It is not surprising why the fulfilment of the vow is ambiguous in the narrative. If it is projected that the Deuteronomist editor really imagined and recounted the Jephthah cult as a chaotic domestic cult, then to support his cult law, he also created an impression of chaos at the end of the story. So, for the ancient listeners, Jephthah's vow and sacrifice were a common thing, but the Deuteronomist editors who refused to sacrifice human life tried to obscure the story mainly because of Yahweh's attitude, whether Jephthah's daughter was slaughtered to support his ideology. Jephthah's daughter requested to cry over her virginity and her annual remembrance of the women are ways through which the Deuteronomist editors build an empathetic impression on listeners and then hopefully reject human victims.

The phrase 'Jephthah the Gileadite' (Yiftakh ha Gileadi) in Judges 11:40b is emphasised by the narrator as the opening of the story (11:1a) and the ending of the story (12:7b). Apart from explaining Jephthah's identity as a Gileadite, the phrase also emphasises the locality of the story. In other words, the narrator is trying to say, 'these are the circumstances when a hero comes from Gilead'. Some commentators opine that the decline in Jephthah's prestige was a result of his vow. O'Connell (1996:92) argued that Jephthah's act of sacrificing his daughter led him to being remembered as a ruthless and arrogant leader of Gilead. Pressler (2002:203-207) saw Jephthah's vow as a sign of a leader's failure to maintain a faith relationship with Yahweh, which has an impact on human sacrifice and social disintegration. Meanwhile, Ackerman (1998:110-115) criticises Jephthah for wanting to bind Yahweh more than to hold on to the Spirit of Yahweh. 
Jephthah's ability to negotiate was first evident in his conversations with the elders of Gilead. But actually, the narrator does not explain Jephthah's characteristics as an intelligent person. The narrator only introduces Jephthah as a mighty man (giborkhayil). Jephthah's diplomacy with the Ammonite king and his negotiations with the Ephraimites indicatee failures. All of those ended in a fighting, which led Jephthah to victory. Jephthah failed to fulfil his function as leader and ruler of Gilead, but succeeded in becoming a commander or warlord.

Jephthah made negotiation with God in his vow to Yahweh. According to Webb (1987:63) Jephthah's vow echoed the conditions when he bargained with the elders of Gilead. The failure of diplomacy with the king of Ammonites did not bring Jephthah to his senses. He was still nostalgic for his success in influencing the elders of Gilead who made him the ruler of all Israel in Trans-Jordan. Jephthah tried to influence Yahweh by offering an uncertain object as sacrifice. What if nothing or no-one came out of his door? The sentence structure or narrative structure in 11:29-40 shows the separation between Yahweh's actions and Jephthah's actions. The narrator begins with an explanation that Yahweh's Spirit came upon Jephthah (11:29a). The phrase wa'ttehi literally means 'then he made' or 'then he took his place'. The coming of the Spirit of Yahweh upon Jephthah was an act of initiative, not a reaction or a causal effect. This information indicates that Yahweh took the initiative to accompany Jephthah before Jephthah made the vow.

The problem was Jephthah suddenly made a vow with Yahweh. The phrase wa'yyidda, which describes Jephthah's actions in verse 30 can be understood as an act of Jephthah's initiative. It was not an act of cause and effect. Taking a vow was indeed a bidder initiative and was not required by Yahweh (Werblowsky \& Wigoder, 1997:716). The narrative structure also shows that the actions of the Spirit of Yahweh and those of Jephthah do not have a causal relationship but rather form two unique story patterns. This chart shows that the situation regarding the coming of the Spirit of Yahweh upon Jephthah is information directly related to Jephthah's conflict and victory over the Ammonites.

A The Spirit of the Lord came upon Jephthah (v. 29)

B Jephthah comes into conflict (physically) with the Ammonites (vv. 29b-32a)

C Jephthah overcomes the Ammonites (vv. 32b-33)

$\mathrm{D}$ The Ammonites are conquered before the children of Israel (v. 33c)

A' Jephthah vows (vv. 30-31)

B' Jephthah experienced conflict with his daughter (vv. 34-38)

$C^{\prime}$ Jephthah fulfilled his vows against his daughter (v. 39d)

D' Memorial tradition of Jephthah's daughter (vv. 39e-40)

Meanwhile, Jephthah's vows are information that is directly related to the conflict and the fulfilment of Jephthah's vow for his daughter. The separation according to the narrative structure between the coming of the Spirit of Yahweh and the vow of Jephthah is sharpened by the absence of Yahweh at the fulfilment of Jephthah's vow. When Jephthah was about to sacrifice his daughter, there is no information about Yahweh's attitude (vv. 35-39). The absence of Yahweh in the story indicates that the Deuteronomist editor, who consistently defended Yahweh, was implicitly trying to show that the vow was entirely Jephthah's responsibility. Any risk from this vow is the responsibility of Jephthah alone. O'Connell (1996:192) even argued that Yahweh's absence was a form of retaliation against Jephthah's arrogance who intended to direct Yahweh to the interests of his ambition.

The failure of Jephthah's function as a leader in Gilead can also be compared with his tenure as a judge of only 6 years, considerably shorter than his predecessors' averaging 40 years. Moreover, there is no information whether as long as Jephthah the giborkayil served as Israel's judge the land would be as safe as the judges before him. The story gives the impression that Jephthah was successful as a war leader, but failed as a political leader. This failure was mainly because of the syncretic and arrogant vow that separated the authority of the Spirit of Yahweh from its initiative. The Deuteronomist editor gave the impression that Jephthah could be appreciated in his commanding capacity.

Through the vow of Jephthah, the editor of Deuteronomy provided an education for the reader or listener to reconsider vowing practices amongst Israel. Jephthah had shown guilt through his vow because he tried to bind and bribe God in such a way, including by putting his family at risk of death, to achieve his goals and thereby establish his honour. Jephthah vowed as he pleased. He chose to direct God to his goal. On the contrary, the Deuteronomist editor appreciated Jephthah, as confirmed by his daughter's statement. In accordance with the Deuteronomic law, Jephthah was committed to act faithfully according to the words that had come out of his mouth. Regardless of whether the victory that the Lord gave was the fruit of his vow, or because of God's initiative, for Jephthah he had vowed and his hopes were fulfilled. He had to keep his promise. He was responsible for his words and actions. In that regard, according to Deuteronomic law, Jephthah was exemplary. The Deuteronomist Editor, however, saw the mixing of cults as the cause of chaos. The Yahweh cult with foreign (or syncretistic) cult must be separated. Foreign and syncretistic cults are associated with wild, uncontrolled and chaotic passions. On the contrary, the exclusive Yahweh cult was categorised as controlled and orderly. The types of victims in the Yahweh cult were predetermined, including prohibitions for human victims, so as to prevent the bidder from vowing intentions that could bring havoc to himself, his family or other humans. Moreover, aiming to protect the vow maker, the Deuteronomist editor also intends to protect the purity of his exclusive cult ideology from being contaminated by foreign cults. The Deuteronomist editor invites exiles so that in the midst of a stressful life (depression) they keep themselves from cults other than Yahweh. Yahweh 
guarantees freedom from foreign hands not because of vow or sacrifices but because of a commitment to abandon foreign worship and to worship Yahweh only.

According to Deutronomist ideology, a leader should be faithful in upholding the law. He is required to ask for guidance from Yahweh God before making a policy. He must be loyal to the cult of Israel and dare to oppose syncretism. Moreover, he should maintain the unity of the tribes of Israel. Jephthah is an example of a leader who does not meet all of these criteria. He is worthy of an example because he faithfully practised the words that had come out of his mouth, as stated in the book of Deuteronomy 23:23. But he chose to impose his will on Yahweh, trying to ensnare Yahweh with his vow, rather than asking Yahweh for guidance. All of these leadership criteria describe the ideology of the Deuteronomist. Therefore, a good leader of the nation of Israel is one who represents the ideology of the Deuteronomist sect. Leaders who were opposed to the ideology of the Deuteronomist were certainly viewed as bad, as illustrated by the major judges from the non-Judaic tribes, including Jephthah. As the kings who represented the Deuteronomic ideal were Josiah, Hezekiah, Asa and David, the dynasty of David was considered a true dynasty in Yahweh's eyes.

\section{Ideology of victory in political vow}

Israel experienced persecution from the tribe of Ammon. The elders of Gilead asked Jephthah to be the leader to fight against them. The summons became Jephthah's moment to restore his social status. Jephthah did not waste this opportunity and used various efforts to gain victory, including through negotiations. Unfortunately, he failed and had to go to war. Jephthah was not sure that he would win against the Ammonites, whilst the victory was important for him to raise his dignity as a man who had experienced discrimination from his brothers. Because of that he considered a vow as the best way (if not the only way) to gain victory. Normally, there was no problem with Jephthah's efforts to restore his rights, including by taking a vow. Even to ensure God's guarantee, in conditions of war as experienced by Jephthah, his choice to make a vow was understandable. The problem with Jephthah's vow was that he simply pointed to all who lived in his house as a fulfilment for his vow. He abused his rights as leader of the family by putting his family members at risk of death for the sake of dignity and the position as a leader of all the people of Gilead. Jephthah did not give Yahweh a chance to instruct him as the heroes before him did. He chose to 'bribe the LORD' instead of asking for his direction. For Jephthah the fighting against the Ammonites was his; a way to gain political office; and so it is not a war that belongs to God. If Yahweh was involved, then to Jephthah Yahweh would have given victory as the answer to his vow, not as the cries of repentance of the people of Gilead and all Israel. Referring to Deuteronomic ideology, Jephthah was even willing to imitate the vow of foreign enemies to guarantee his victory. Through the story of Jephthah's vow, the Deuteronomic editor implies that making a vow, especially by imitating foreign cults, is not a solution, but rather it creates new problems. The Deuteronomic editor chose to strengthen the identity of Yahwism in exile, write the history of the nation to maintain the continuity of existence in a foreign land, and activate educational associations, whilst waiting for God to act by sending a liberator, namely a messiah (Yahweh's chosen one).

On the one hand, The ideology of the Deutronomist about the true leader of Judah (and Israel) is Israelite or Judean with an exclusivistic view, antiforeign, the true leader of Judah (and Israel) is Israelite or Judean with an exclusivistic view, anti-foreign, capable of unifying all of Israel and representing the ideology of the Deuteronomic belief. On the other hand, a syncretist Yahwist, affiliated with foreigners, fails to unite and does not represent that the ideology of the Deuteronomist is seen as evil. Jephthah did not meet these criteria mainly because he did not represent the ideology of the Deuteronomic belief. He is depicted as acting in the cultic spirit of a foreign nation and failing to comply with the Deuteronomic victimisation law. Through the story of Jephthah, the Deuteronomic historians warned the Israelite elite about the dangers of a cult following foreign, when they are under foreign pressure. According to the Deuteronomic historians, the elite of Judah (as well as Israel) had imitated Assyria. To get the peace of the conquering kingdom, the elites followed the Assyrian cult. The imitation of the conquering kingdom is also manifested in socio-political life: gaining power at the expense of other people's lives. The Deuteronomist, through Josiah's reforms, opposed the elites and their foreign policy through discourses and purification movements. Deuteronomists believe that the original identity of the Israelites is bound by an exclusivistic covenant with Yahweh. Therefore, they build a dichotomous discourse. Syncretic worshippers who are considered sinful are contrasted with those who adhere to an exclusivistic view of Jahweh who is claimed to be holy. A syncretic leader is seen as evil whilst an exclusivistic leader is considered righteous. Such dichotomy discourse is emphasised by strict separation laws, for example the law of clean and unclean or blessing and curse. The assassination of a syncretist propagator and cult leader is justified. The leaders (elites) who imitated (mimicry impulse) the cult and the political style of the conquering kingdom, as well as the leaders (elites) who opposed the dichotomous discourse had both committed acts of violence, discrimination and domination over others.

The ideology of victory characterised by self-worship seeks a place of safety and comfort. The ideology of victory is often also characterised by a desire to 'be the head not the tail'. Faith is evidenced by success to excel (if not dominate) others. If this understanding meets the text of Hebrews 11:32, then Jephthah, who succeeded in becoming the head of Gilead, succeeded in defeating foreign enemies, and his vow to God and his willingness to sacrifice his daughter were exalted and imitated without caring about the injustice experienced by the girl. In this ideology, drawing closer to the Lord is meant to take refuge in the hand of the Lord, with words from the Psalms 'under your wings, you take me high ... like an eagle'. What happens if the vow meets the ideology of victory? It is conceivable that 
the vow will become a part of self-worship. Whether under difficult or normal conditions, when the desire to win, excel and dominate, a vow can easily become a medium to 'urge' the Lord to fulfil the purpose of the bidder, in the name of faith. In this context, Soelle's (2001:61) idea is relevant in criticising the motivation for worshiping Jahweh; Jahweh is not an object, which we can control at will to fulfil our desires.

An significant voice is Jephthah's vow categorized as political vow the category of 'political vow'. The term vow here is not always related to an oath or promise to the Lord but an oath or promise to oneself or another person to do something if their wish comes true. We can already imagine that one of its forms is a political campaign, which is almost certain to be rejected by politicians if it is called 'political vow', but in my opinion, the form, which promises to do something if its desire is achieved, can be categorised as voting. Within certain limits the voters' political vow become entertainment in the middle of a democratic party. But the thing to watch out for is when the people who make the vow are controlled by the ideology of victory and then cause an excessive vow, namely various forms of vows that go beyond the limit and cause their dignity or other people to become a victim. On the contrary, the political vow of people can also contain a reflective message for the elite. Apart from being a form of joy of victory, this action also presumably reprimands the elite it has chosen to fulfil the commitments that have been conveyed during the campaign period or fulfil their oath or promise of office before carrying out their entrusted responsibilities.

\section{Conclusion}

This study argues that the Jephthah's vow contains political elements. Firstly, the motivation aspect includes intentions, hopes and goals of his vow. Jephthah meant to 'bribe Jahweh' because he hoped for victory to maintain his honour and dignity. Secondly, it is the victim aspect. Burnt offering is the object that he promised to Jahweh if his hope about the vow is fulfilled. Jephthah promised an uncertain conditional object. The condition of the object he promised threatened the lives of those in his house. Thirdly, it is the attitude aspect. Jephthah's way of vowing shows an attitude that treats Jahweh as if it were an easy subject to be controlled by the burnt offering. Fourthly, it is the aspect of fulfilling the vow. Jephthah was obliged to fulfil his vow as proof of his religiosity, demands of social responsibility and legal obligations. The four aspects of the vow are like inseparable links. Mistakes in one aspect alone can have a fatal impact on other aspects. Jephthah's commitment to fulfilling his vow can be appreciated. But his mistakes in the first to third aspects have brought his daughter to disaster.

\section{Acknowledgements Competing interests}

The authors declare that they have no financial or personal relationships that may have inappropriately influenced them in writing this article.

\section{Authors' contributions}

M.T. and N.N.N. contributed equally to this work.

\section{Ethical considerations}

This article followed all ethical standards for a research without direct contact with human or animal subjects.

\section{Funding information}

This research received no specific grant from any funding agency in the public, commercial or not-for-profit sectors.

\section{Data availability}

Data sharing is not applicable to this article as no new data were created or analysed in this study.

\section{Disclaimer}

The views and opinions expressed in this article are those of the authors and do not necessarily reflect the official policy or position of any affiliated agency of the authors.

\section{References}

Ackerman, S., 1998, Warrior, dancer, seductress, queen: Woman in judges and biblical Israel, Doubleday, New York, NY.

Ambrose, 1975, 'On the duties of the clergy', in P. Schaff \& H. Wace (eds.), Nicene and post-Nicene fathers, 2 nd Ser., Vol. 10, pp. 1-325, William B. Eerdmans, Grand Rapids, MI.

Augustine, A., 1995, 'Quaestiones in Heptateuchum', in J.P. Migne (ed.), Patrologia Latina, Vol. 2, pp. 1-511, New City, New York, NY.

Cartledge, T.W., 1992, Vows in the Hebrew Bible and the ancient near east, Sheffield Academic Press, Sheffield.

Clines, D.J.A., 1995, Interested parties: The ideology of writers and readers of the Hebrew Bible, Sheffield Academic, Sheffield.

Janzen, D., 2005, 'Why the Deutoronomists told about the sacrifice of Jephthah's daughter?', Journal for the Study of Old Testament 29(3), 339-357. https://doi. org/10.1177/0309089205052681

Logan, A., 2009, 'Rehabilitating Jephtah', Journal of Biblical Literature 128(4), 665-685. https://doi.org/10.2307/25610213

Macherey, P., 1978, A theory of literary production, Routlege and Keagen Paul, London.

Malina, B.J., 1996, 'Mediterranean sacrifice: Dimension of domestic and political religion', Biblical Theology Bulletin 26(1), 26-44. https://doi.org/10.1177/ 014610799602600104

McKenzie, S.L., 2010, Introduction to the historical books: Strategies for reading, Wm.B. Eerdmans Publishing Co, Grand Rapids, MI.

Meyers, 226 C., 1997, 'The family in early Israel', in L.G. Purdue (ed.), Families in ancient Israel, pp. 18-19, Westminster John Knox Press, Louisville, KY.

O'Connell, R.H., 1996, The rhetoric of the book of judges, E. J. Brill, Leiden.

Pressler, C., 2002, Joshua, judges, and ruth, Westminster Jhon Knox Press, Louisville, KY.

Pseudo-Philo, 1985, 'Liber AntiquitatumBiblicarum', in J.H. Charlesworth (ed.), The Old Testament Pseudepigrapha, pp. 10-11, Doubleday \& Co, Garden City, NY.

Singgih, E.G., 2018, Korban Dan Pendamaian: Studi Lintas IImu, Lintas Budaya, Dan Lintas Agama Mengenai Upaya Manusia Menghadapi Tantangan Terhadap Kehidupan Di LuarKendalinya, BPK GunungMulia, Jakarta.

Smith, M., 1987, Palestinian parties and politics that shaped the Old Testament, SCM, London.

Soelle, D., 2001, The silent cry, Fortress Press, Minneapolis, MN.

Webb, B.G., 1987, The book of the judges: An integrated reading, Sheffield Academic Press, Sheffield.

Werblowsky, R.J,Z \& Wigoder, G, 1977, The Oxford dictionary of the Jewish religion, Oxford University Press, New York, NY.

Yee, G.A., 1995, 'Ideological Criticism: Judges 17-21 and the dismembered body', in G.A. Yee (ed.), Judges and method, new approaches in biblical studies, pp. 138-265, Fortress Press, Minneapolis, MN.

Yee, G.A., 1999, 'Ideological criticism', in J.H. Hayes (ed.), Dictionary of biblical interpretation, pp. 534-537, Abingdon, Nashville, TN. 